\title{
保育施設の園外活動による都市公園利用様態と利用者属性との関係性
}

\section{Analysis of the relationships between nursery schools' urban park usages as out of school activities and their infants' attributes}

\author{
椎野 亜紀夫*
}

\section{Akio SHIINO}

\begin{abstract}
This paper aimed at clarifying the current circumstances of infants' out of school activities of nursery schools in urban parks, and analyzing the relationships between urban park usage and users' attributes, such as infants' age. The result of spatial analysis using GIS revealed the differences of the range of urban park usage between nursery schools and kindergartens. And through the investigation of the comparison among the presence of urban park facilities and urban park usage, it was clarified that infants under the age of two did not need lavatories in urban parks because many of them were in a diaper, while the infants over the age of three required lavatories during their use of urban parks as nursery schools' out of school activities. Moreover, though seals were recently put on the certain play equipments in urban parks which showed their target age of children, it was clarified that such announcement excessively regulated infants' uses of play equipments.
\end{abstract}

Keywords: urban park, nursery school, out of school activity, infants'attributes, GIS キーワード：都市公園，保育施設，園外活動，幼児の属性，地理情報システム

\section{1. はじめに}

都市における幼児の健全な発達を促寸活動として外遊びは重要 であり, 屋外オープンスペースは保育の場としての機能を担って いる。近年，保育施設の屋外活動にとどまらない保育を通じた地 域資源の関係性構築を目指した「まち保育」という概念が二輪ら 1)により提唱されているが，このようなしくみを実現させていく ためにも保育活動がしやすい園外環境整備は重要である。保育所 における保育の内容を定めた保育所保育指針 ${ }^{2)}$ においては, 健康 に関わるねらい及び内容の一端として「健康な心と体を育て，自 ら健康で安全な生活をつくり出す力を養う」ために「進んで戸外 で遊ぶ」必要性がうたわれ，特に三歳以上児の保育に関わる配慮 事項として「様々な遊びの中で，全身を動かして意欲的に活動す ることにより，体の諸機能の発達が促されることに留意し，子ど もの興味や関心が戸外にも向くようにする」ことが示されている。 また幼稚園の教育内容を定めた幼稚園教育要領 ${ }^{3)}$, 認定こども園 の教育内容を定めた幼保連携型認定こども園教育・保育要領 4 に おけるねらいとして「進んで戸外で遊ぶこと」が掲げられている。 都市部における身近な園外活動場所として，市街地内に多数設置 されている都市公園がその役割の一端を担うことが期待される。 保育所や幼稚園等の園外活動の場所として都市公園が利用される 際の特徴として 1 . 保育所ではおおお斿 1 歳〜 5 歳, 幼稚園ではお おむね 3 歳〜 5 歳の幼児で構成される集団利用である点, 2 . 少数 の保育士や教諭が多数の幼児を引率するという利用者構成である 点，の 2 つが想起される。これらの点において，個人等による一 般公園利用とは異質の利用形態を有しており，その特殊性を考慮 した利用計画，施設計画の必要性が指摘される。

都市計画をはじめとする計画学分野においては, これまで保育 所や幼稚園等による園外空間利用に関する調査・研究がなされつ つあり, 園外活動の実態からみた地域資源のあり方に関する研究 5), 屋外遊戯場としての都市公園の代替利用に関寸る研究 ${ }^{6)}$, 園外 活動の場としての街区公園利用とその評価 ${ }^{7}$, 保育施設の立地状
況と都市公園分布との関係性 ${ }^{8}$ など, 一定の研究蓄積が見られる。 本研究はこれらの既存研究に続く保育施設 ${ }^{9}$ の園外活動に着目し た研究と位置づけられ, 市街地内に数多く存在している都市公園 の中から保育施設の園外活動の場としてどの公園が，どのように 保育施設によって利用されているのかを明らかにしようとするも

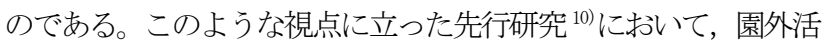
動の場としての都市公園利用状況を引率する幼児の年齢等との関 係から分析を試みているが，本稿においては同様の研究方法を他 地域で実施し既存研究成果を検証するとともに，保育施設の園庭 11)の有無が園外活動としての都市公園利用に与える影響や, 園外 活動利用における都市公園の課題・要望等の解明を通じて，既存 研究成果の深化を試みた。具体的には各保育施設の基本条件（幼 児人数, 園外活動における年齢構成, 園庭の有無等）を整理した 上で，保育施設からの距離や都市公園面積，公園施設等といった 空間条件と, 引率する幼児の年齢等による利用ニーズの差異とい った利用者属性という 2 つ側面から園外活動の場としての都市 公園利用の実態と特徴を解明し, 保育施設の園外活動促進に向け た都市公園のあり方に関する検討を行うことをねらいとした。本 稿で対象とする保育施設とは前述のように保育所, 幼稚園, 認定 こども園を含めた用語と定義するが，園庭の有無に着目したのは 幼稚園は園庭が必置, 認定こども園・満 2 歳児以上が入所する認 可保育所は園庭が原則設置であるのに対し, 認可外保育所では園 庭が必置ではないこと, また園庭を有する場合でも面積規模が保 育施設により異なることが想定され，このことが都市公園の園外 活動利用に関係するのではないかと考えたためである。すなわち 本研究は, (1)各保育施設における幼児人数や園外活動における年 齢構成, 園庭の有無等の基本条件を整理した上で, 保育施設の園 外活動の場としての都市公園利用の実態について把握する, (2)園 外活動の場として利用される都市公園の空間的特徴（保育施設か らの距離, 公園面積等）について明らかにする, (3)引率する幼児 の年齢など利用者属性と目的(1)(2)との関係性について分析・考察

\footnotetext{
*札幌市立大学デザイン学部
} 
する,の 3 点を研究目的とした。

\section{2. 研究対象地 - 研究方法}

保育施設による園外活動の場としての都市公園利用について, 札幌市清田区を対象とした調査を実施した。調査は，当該地区の 都市公園を管理する札幌市清田区土木センターとの共同調査とし て実施し，各保育施設に訪問して調查趣旨を説明した上で調查協 力を依頼, 同意が得られた施設の職員にアンケート調査票を留置 し項目の記入を依頼した。調査票は各年齢のクラスごとに 1 部ず つ手渡し，クラス担任に園外活動でどの都市公園をどのように利 用しているのか記入いただくよう依頼した。またその際，都市公 園の位置や名称が特定しやすいよう，各保育施設を中心とする半 径 $1 \mathrm{Km}$ の範囲に立地する都市公園マップを添付した。後日，調査 票の回収に再訪問して調査票の記述内容を確認しながら，各保育 施設職員に対するヒアリング調査を行った。対象地区内の認定こ ども園 2 力所, 認可保育所 10 力所, 認可外保育所 5 力所, 幼稚園 8 力所の合計 25 力所を対象として調査協力を依頼し, うち認定こ ども園 2 力所, 認可保育所 10 力所, 認可外保育所 4 力所, 幼稚園 7 力所の合計 23 力所から有効回答を得た (有効回答率 $92.0 \%$ )。調 査は 2016 年 1 月〜2016 年 3 月の期間に実施した。

回収したアンケート調査票の記述内容を表計算ソフト Microsoft Excel を用いて集計し, 公園利用の実態について抽出・ 整理した。各保育施設が園外活動の場として日常的に利用してい る公園について, 利用する公園名, 利用する幼児の年齢, 利用内 容, 公園までの移動手段, 利用上の課題・要望について, アンケ 一ト調査票の記載内容をデータ入力した。また各保育施設の幼児 人数と園外活動における年齢構成, 園庭の有無（有りの場合は面 積規模) について把握した。さらにGIS ソフトArcGIS を用いて対 象地域の都市公園分布の把握と，各保育施設を中心として利用が 確認された都市公園までの Spider Diagram を作成し, 各保育施設 から利用都市公園までの直線距離を計測した。この結果をグラフ 作成ソフトDelta Graph を用いて各保育施設から利用が見られた 都市公園までの直線距離を横軸，公園面積を円の直径とするバブ ルチャートを作成し，保育施設一利用都市公園間の利用距離分布 を比較，考察した。

また前述のようにアンケート調査票回収時に各保育施設職員へ のヒアリング調査を行い, 幼児の人数, 園庭の有無のほか, アン ケート調査票の記入内容を確認しながら詳しい状況の聞き取りを 行った。得られた言説を定性的に分類・整理して出現頻度を項目 別に計数し，保育施設による都市公園利用に関して指摘件数の多 かった内容 (言説) をデータとして整理した。さらに定量データ との比較を通じて保育施設が園外活動の場として都市公園をどの ように，またどのような理由で選択的に利用しているのか解明を 試みた。なお GIS で使用したデータのうち，道路と保育施設は国 土数值情報 ${ }^{12)}$ の公開データを使用し, 都市公園は札幌市建設局み どりの推進部に依頼し提供を受けたデータを使用した。

\section{3. 研究結果}

\section{（1）対象保育施設の概要}

本研究において調査対象とした保育施設 23 力所(認定こども園 2 力所, 認可保育所 10 力所, 認可外保育所 4 力所, 幼稚園 7 力 所）の概要を表一 1 に示した。各保育施設の公立/私立の区分, 調査時点における在籍幼児人数, 年齢別構成人数について整理し た。在籍人数は各保育施設によって異なり, 最大 300 名を超える 施設から最小 10 数名の施設まで差異が見られた。施設の区分に よる差異として，認可外保育所についてはいずれも 30 名に満た ない小規模な在籍人数であったこと, 幼稚園は在籍年齢が満 3 歳 児以上（2歳児保育を行っている 1 力所を除く）であったことか

\section{表一1 対象保育施設の概要}

\begin{tabular}{|c|c|c|c|c|c|c|c|c|c|c|c|c|}
\hline \multirow{2}{*}{$\begin{array}{c}\text { 施設 } \\
\text { No. } \\
\end{array}$} & \multirow{2}{*}{ 施設区分 } & \multirow{2}{*}{ 公私 } & \multirow{2}{*}{ 人数 } & \multicolumn{6}{|c|}{ 年魿別人数 } & \multicolumn{2}{|c|}{ 日常的な園外活動年龃構成幼幼児) } & \multirow{2}{*}{$\begin{array}{c}\text { 園㾋の有無 } \\
\text { (面積) }\end{array}$} \\
\hline & & & & 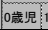 & 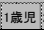 & 2 & 3葴归 4 4跲 & 檅昆 5 肯 & 旊昆 & 年軨別 & 異年粗 & \\
\hline 1 & \multirow{2}{*}{ 認定こども園 } & 公立 & 113 & 8 & 11 & 11 & 20 & 30 & 33 & $\bullet$ & & 有り $\left(651 \mathrm{~m}^{3}\right)$ \\
\hline 2 & & 私立 & 395 & 5. & 12 & 8 & \begin{tabular}{|l|l|}
130 & 1 \\
\end{tabular} & 120.1 & 120 & $\bullet$ & & 有り $\left(823 \mathrm{~m}^{2}\right)$ \\
\hline 3 & \multirow{10}{*}{ 認可保育所 } & 私立 & 184 & 12. & 34 & 35 & 35 & 33 & 35 & - & [345歲児] & 有以 $\left(1,110 \mathrm{~m}^{2}\right)$ \\
\hline 4 & & 私立 & 128 & 20 & 21 & 21 & 22 & 22 & 22 & & [345椷児] & 有り $\left(270 \mathrm{~m}^{\prime}\right)$ \\
\hline 5 & & 私立 & 97 & 12 & 18 & 20 & 18 & 16 & 13 & - & [345煘児」 & 有り $\left(240 \mathrm{~m}^{\prime}\right)$ \\
\hline 6 & & 私立 & 60 & 4 & 8 & 9 & 14 & 13 & 12 & & 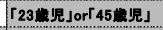 & 有り $\left(880 \mathrm{~m}^{2}\right)$ \\
\hline 7 & & 私立 & 113 & 14 & 20 & 19 & 19 & 21 & 20 & $\bullet$ & 「345桐児」 & 有り(515 $\left.\mathrm{m}^{\circ}\right)$ \\
\hline 8 & & 私立 & 117 & 15 & 20 & 16 & 25 & 22 & 19 & - & 「345歲児」 & 有り $\left(879 \mathrm{~m}^{2}\right)$ \\
\hline 9 & & 私立 & 62 & 7 & 10 & 10 & 13 & 10 & 12 & - & 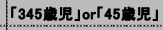 & 有り $\left(239 \mathrm{~m}^{2}\right)$ \\
\hline 10 & & 私立 & 1111 & 12. & 19 & 20 & 20 & 19 & 21 & - & 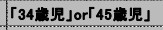 & 有り $\left(488 \mathrm{~m}^{\prime}\right)$ \\
\hline 11 & & 私立 & 99 & 10 & 17 & 18 & 18 & 18 & 18 & $\bullet$ & 「345歲児」 & 有り $\left(201 \mathrm{~m}^{2}\right)$ \\
\hline 12 & & 私立 & 90 & 11 & 14 & 17 & $\mid 17$ & 16 & 15 & & 「345歳児」 & 有り $\left(217 \mathrm{~m}^{\prime}\right)$ \\
\hline 13 & \multirow{4}{*}{ 認可外保育所 } & 私立 & 15 & 2 & 1 & 6 & 3 & 1 & 2 & & 「12345喊児」 & 無ᄂ \\
\hline 14 & & 私立 & 25 & 2. & 2. & 6 & 4. & 6 . & 5 & & 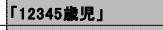 & 無L \\
\hline 15 & & 私立 & 11 & 1 & 4 & 1 & 2 & 0 & 3 & & [12345哃児」 & 無L \\
\hline 16 & & 私立 & 21 & 0 & 6 & 12 & 3 & 0 & 0 & & 「12345歳児」 & 無し \\
\hline 17 & \multirow{7}{*}{ 幼稚園 } & 私立 & 299 & & & & \begin{tabular}{l|l}
84 & 1 \\
\end{tabular} & \begin{tabular}{|c|c|}
104 & 1 \\
\end{tabular} & 111 & - & & 有り $\left(4,203 \mathrm{~m}^{2}\right)$ \\
\hline 18 & & 私立 & 210 & & & & 69 & 71 & 70 & - & & 有り $\left(709 m^{2}\right)$ \\
\hline 19 & & 私立 & 118 & & & & 42 & 29 & 47 & - & & 有り $\left(1,174 \mathrm{~m}^{2}\right)$ \\
\hline 20 & & 私立 & 306 & & & 26 & 80 & 93 & 107 & $\bullet$ & & 有り $\left(5.082 \mathrm{~m}^{2}\right)$ \\
\hline 21 & & 私立 & 126 & & & & 21 & 52 & 53 & $\bullet$ & & 有り $\left(2,853 \mathrm{~m}^{\prime}\right)$ \\
\hline 22 & & 私立 & 112 & & & & 37 & 33 & 42. & - & & 有以 $\left(1,876 \mathrm{~m}^{2}\right)$ \\
\hline 23 & & 私立 & 160 & & & & 60 & 48 & 52 & $\bullet$ & 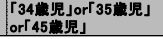 & 有り $\left(850 \mathrm{~m}^{\circ}\right)$ \\
\hline
\end{tabular}

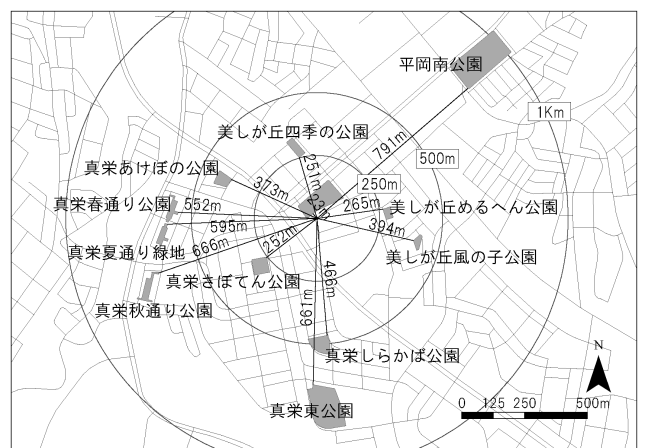

図-1 利用都市公園分布事例 認可保育所（施設 No. 7)

ら，0歳児から受け入れをしている他の保育施設と差異が見られ た。一方でヒアリング調査の中で, 特に認可保育所においては 3 歳児以上の幼児クラスの園外活動における年齢構成として(1)主と して年齢別クラスで引率・活動する, (2)主として 3 歳児・4 歳児・ 5 歳児の異年齢クラスで引率・活動する, (3)活動目的によって (1) (2)を使い分けている，の3 タイプがあることが確認された。この ことから, 表一 1 の項目に基本情報として 3 歳児以上の幼児を引 率して園外活動を行う際の集団の年齢構成について記載した。表 中では年齢別クラスで園外活動を行うか否かを該当：「○」, 非該 当：「(空欄)」で示し，異年齢クラスで園外活動を行う場合は引率 する幼児の年齢構成を記載した。この結果, 認定こども園, 幼稚 園では 1 力所を除くすべて年齢別クラスで園外活動を行っていた のに対し, 認可保育所では 3 歳児以上の幼児を引率する園外活動 は 10 力所中 7 カ所が年齢別クラスまたは異年齢クラスで, 10 カ 所中 3 カ所では異年齢クラスのみで行っていた。また認可外保育 所については, 本研究で対象とした 4 カ所寸べての保育施設で全 年齢を引率した園外活動を行っていたが，その理由として引率す る保育士の人数が限られており, 複数のグループに分けて園外活 動を行う余裕がないことがヒアリング調査の結果から確認された。 さらに各保育施設の園庭の有無と, 園庭がある場合はその面積に ついも整理した。その結果, 認定こども園, 認可保育所, 幼稚 園についてはすべて園庭が設置されていたのに対し，認可外保育 所ではすべて園庭が設置されていない結果となった。園庭の面積

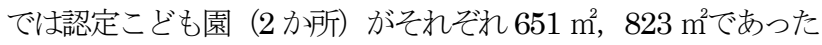
のに対し, 認可保育所 (10 か所) では最大 $1,110 \mathrm{~m}^{2}$, 最小 201 $\mathrm{m}^{2}$, 幼稚園 (7 か所) では最大 $5,082 \mathrm{~m}^{2}$, 最小 $709 \mathrm{~m}^{2}$ となり, 幼 稚園では比較的面積規模の大きい園庭が設置されていたのに対し て, 認可保育所では面積規模が小さい事例が多く見られ, 保育施 設の区分による差異が見られた。 


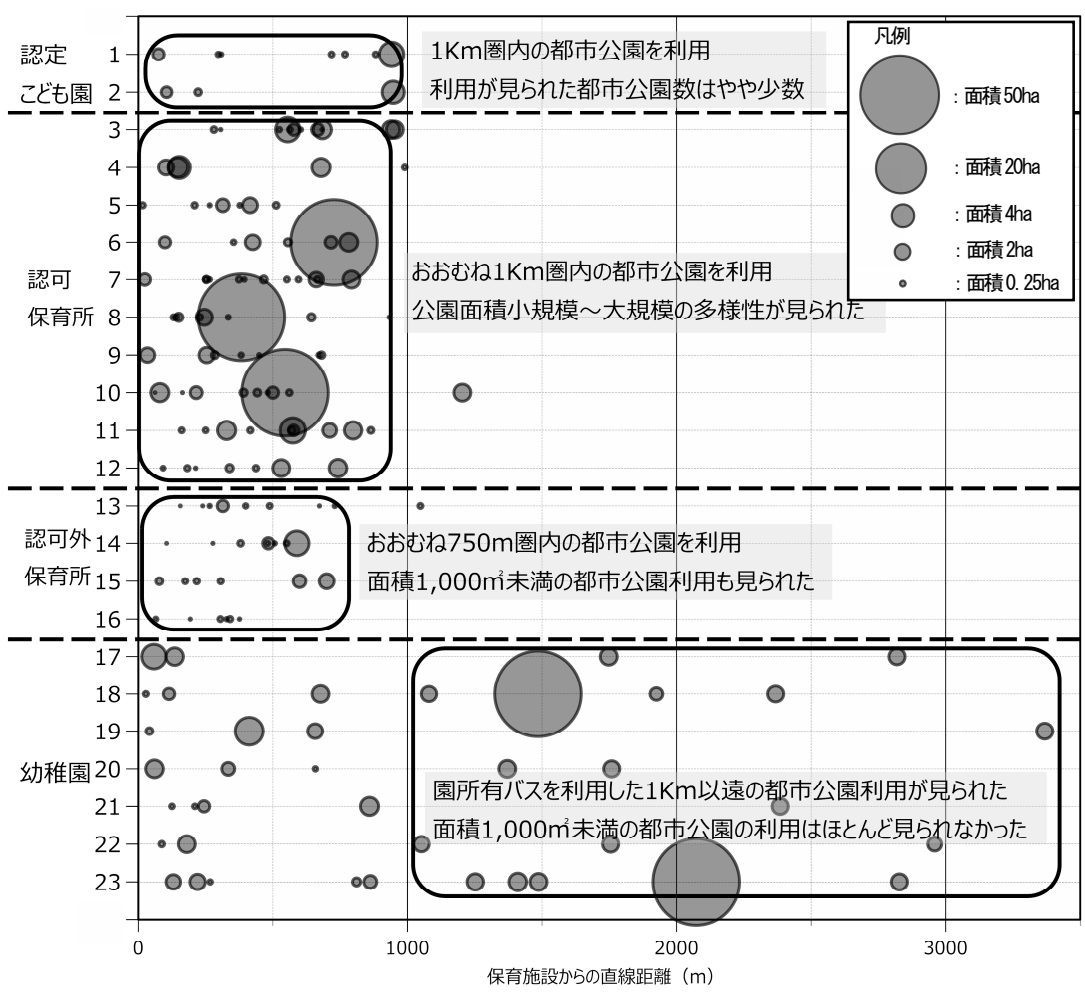

表一2 利用有り都市公園数（施設区分 $\times$ 各施設からの距離）

\begin{tabular}{|c|c|c|c|c|c|c|}
\hline 分類 & $\begin{array}{c}250 m \\
\text { 以内 }\end{array}$ & $\begin{array}{c}250 \mathrm{~m} \sim \\
500 \mathrm{~m}\end{array}$ & $\begin{array}{c}500 \mathrm{~m} \sim \\
750 \mathrm{~m}\end{array}$ & $\begin{array}{c}750 \mathrm{~m} \sim \\
1 \mathrm{Km}\end{array}$ & $\begin{array}{l}1 \mathrm{Km} \\
\text { 以遠 }\end{array}$ & 合計 \\
\hline \multirow{2}{*}{$\begin{array}{l}\mid \begin{array}{l}\text { 認定こども園 } \\
\text { (2力所) }\end{array} \\
\end{array}$} & 3 & 2 & 1 & 4 & 0 & 10 \\
\hline & $30.0 \%$ & $20.0 \%$ & $10.0 \%$ & $40.0 \%$ & $0.0 \%$ & $100.0 \%$ \\
\hline \multirow{2}{*}{$\begin{array}{l}\text { 認可保育所 } \\
\text { (10力所) }\end{array}$} & 22 & 28 & 28 & 8 & 1 & 87 \\
\hline & $25.3 \%$ & $32.2 \%$ & $32.2 \%$ & $9.2 \%$ & $1.1 \%$ & $100.0 \%$ \\
\hline \multirow{2}{*}{$\begin{array}{l}\text { 認可外保育所 } \\
\text { (4力所) }\end{array}$} & 8 & 13 & 7 & 0 & 1 & 29 \\
\hline & $27.6 \%$ & $44.8 \%$ & $24.1 \%$ & $0.0 \%$ & $3.4 \%$ & $100.0 \%$ \\
\hline \multirow{2}{*}{$\begin{array}{l}\text { 幼稚園 } \\
\text { (7力所) } \\
\end{array}$} & 13 & 3 & 3 & 3 & 18 & 40 \\
\hline & $32.5 \%$ & $7.5 \%$ & $7.5 \%$ & $7.5 \%$ & $45.0 \%$ & $100.0 \%$ \\
\hline \multirow{2}{*}{ 合計 } & 46 & 46 & 39 & 15 & 20 & 166 \\
\hline & $27.7 \%$ & $27.7 \%$ & $23.5 \%$ & $9.0 \%$ & $12.0 \%$ & $100.0 \%$ \\
\hline
\end{tabular}

図一2 各保育施設から見た利用有り都市公園の距離・面積分布

\section{（2）保育施設による園外活動場所の空間解析結果}

GIS による空間解析を行い，各保育施設から園外活動の場とな る複数の都市公園までの Spider Diagram を作成し，各線分の距 離を計測した（作図例を図一 1 として提示した）。この結果をもと に，各保育施設から都市公園までの直線距離を横軸としたバブル チャートを作成した（図一2）。なお図中の円の大きさを都市公園 面積として表した。保育施設の区分 (認定こども園, 認可保育所, 認可外保育所，幼稚園）別に見ると，利用が見られた都市公園の 距離分布には差異が認められた（図一 1 , 図一 2 , 表一 2 )。認定こ ども園（2 カ所）では，施設から $1 \mathrm{Km}$ 圈内の都市公園利用が見 られたが，利用が見られた都市公園数はやや少数であり，面積 0.1ha〜 5ha 程度の都市公園で利用が見られた。認可保育所 (10 カ所）では認定こども園と同様に，利用が見られた都市公園はほ ぼすべて保育施設から $1 \mathrm{Km}$ 圈内に立地していた（87 カ所中 86 カ所で $98 \%$ 以上，表一2）が，利用が見られた都市公園の面積は 最小 $0.1 \mathrm{ha}$ 未満から最大 $60 \mathrm{ha}$ 以上まで差異が見られた。利用が 見られた都市公園数は表一 2 に示したように認定こども園, 幼稚 園と比較して多い傾向が見られたが，表一 1 で示した通り園庭の 面積規模が比較的小さく，年齢別クラスごとに園庭と園外の都市 公園を使い分けているためではないかと推察された。一方で認可 外保育所 (4 力所) では，おお拉各保育施設から $750 \mathrm{~m}$ 圈内の 都市公園に利用が分布（29 カ所中 28 力所で $95 \%$ 以上，表-2)

しており，他の施設区分と比較して面積が 0.1 ha に満たない事例 を含む比較的小規模な都市公園に利用が集中寸る傾向が見られた。 表一 1 に示した通り認可外保育所はすべて園庭を所有しておらず, 近隣の都市公園を園外活動の場として活用していると考えられる が，一方で職員の人数もあまり多くはないこと，園外活動の際は 1 歳児から 5 歳児までを引率して外出する状況となっている。こ のことから年齢クラス別に活動できる認可保育所等と比較すると, 利用できる公園数や移動距離が限定的となっているのではないか と考えられた。これに対して幼稚園では，保育施設から $250 \mathrm{~m}$ 以 内の都市公園利用（40 力所中 13 力所の $32.5 \%$, 表一2) と保育 施設から $1 \mathrm{Km}$ 以遠 ${ }^{13}$ ）（40 力所中 18 力所の $45.0 \%$, 表一2）に
二極化する傾向が見られた。このうち $1 \mathrm{Km}$ 以遠への（最大約 $3.7 \mathrm{Km}$ 離れた）都市公園の園外活動利用においては, 各幼稚園で 所有する送迎バスを園外活動の移動手段として使用していること が確認され，これが他の保育施設区分と大きく異なる広域な園外 活動範囲を形成する理由となっていた。また面積では最小 $0.2 \mathrm{ha}$ から最大 60 ha 超までの都市公園が活動場所として利用されてお り, 面積 0.1 ha に満たない小規模な都市公園の利用は見られなか

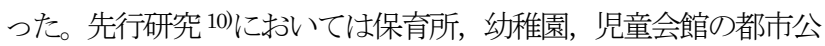
園利用を比較した結果が示されているが，このうち保育所，幼稚 園の距離分布で類似の傾向が見られ, 既存研究成果の妥当性が確 認された。

またこれとは別に，園外活動の場として利用が見られた都市公 園，および利用が見られなかった都市公園を含め，各保育施設周 辺における都市公園分布についての実態把握を行った（図一3）。 この結果, 本研究で対象とした認定こども園ならびに認可外保育 所については, 特に各保育施設から $500 \mathrm{~m}$ 圏内には最大でも面積 約 1 ha の都市公園が 1 力所程度しか分布しておらず, 徒歩での園 外活動における面積規模の大きい都市公園の選択肢が認可保育所, 幼稚園と比較して乏しい状況であることが確認された。また，各 保育施設から $250 \mathrm{~m}, 500 \mathrm{~m}, 750 \mathrm{~m}, 1 \mathrm{Km}$ の距離区分に分け, 各距離区分に含まれる都市公園の利用の有無を面積規模（1,000 $\mathrm{m}^{2}$ 未満/ $1,000 \mathrm{~m}^{2}$ 以上） ${ }^{14)}$ により比較した結果, 各保育施設から $250 \mathrm{~m}$ 以内で利用が見られた都市公園は, 面積 $1,000 \mathrm{~m}^{2}$ 以上では 43 力所中 37 力所 (86.0\%) 見られたのに対して面積 $1,000 \mathrm{~m}^{2}$ 未 満では 20 カ所中 7 カ所 $(35.0 \%)$ にとどまった（図－4）。また $250 \mathrm{~m} \sim 500 \mathrm{~m}$ の距離区分では利用有り都市公園は面積 $1,000 \mathrm{~m}^{2}$ 以上では 91 力所中 41 力所 (45.1\%) であったのに対し面積 1,000 未満では 78 力所中 5 力所 $(6.4 \%), 500 \mathrm{~m} \sim 750 \mathrm{~m}$ の距離区分で は利用有り都市公園は面積 $1,000 \mathrm{~m}^{2}$ 以上では 165 力所中 37 力所 (22.4\%) であったのに対し面積 $1,000 \mathrm{~m}^{2}$ 未満では 120 カ所中 2 カ所 $(1.7 \%)$ のみにとどまるなど, 保育施設からの距離が遠くな るにしたがって面積規模の小さい都市公園の利用比率が顕著に減 少していくことが明らかとなった。 

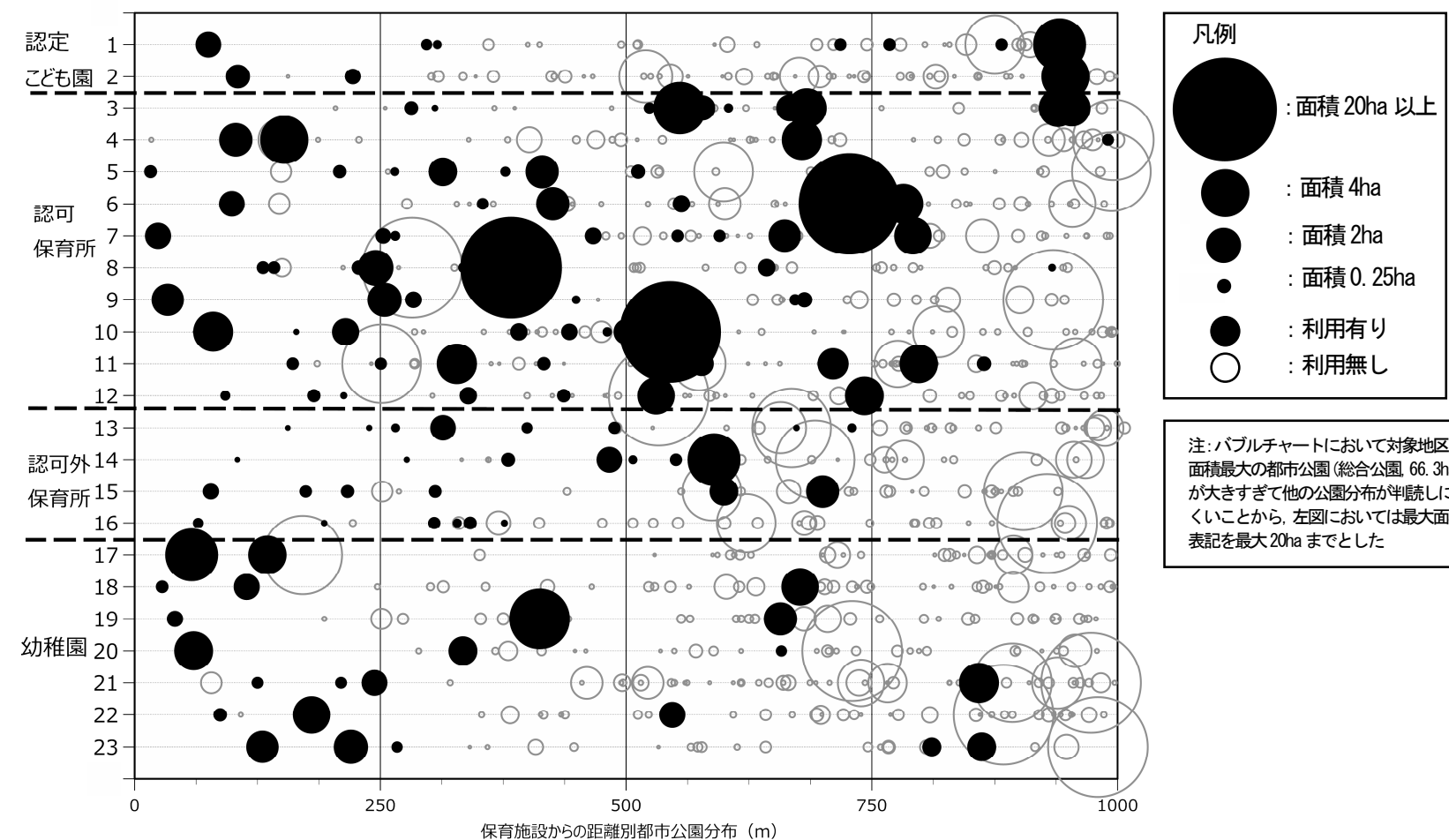

注:バブルチャートにおいて対象地区内 面積最大の都市公園 (総合公園, 66. 3ha) が大きすぎて他の公園分布が判読しに くいことから, 左図においては最大面積 表記を最大20ha までとした

図-3 各保育施設周辺の都市公園分布（施設区分 $\times$ 各施設からの距離）

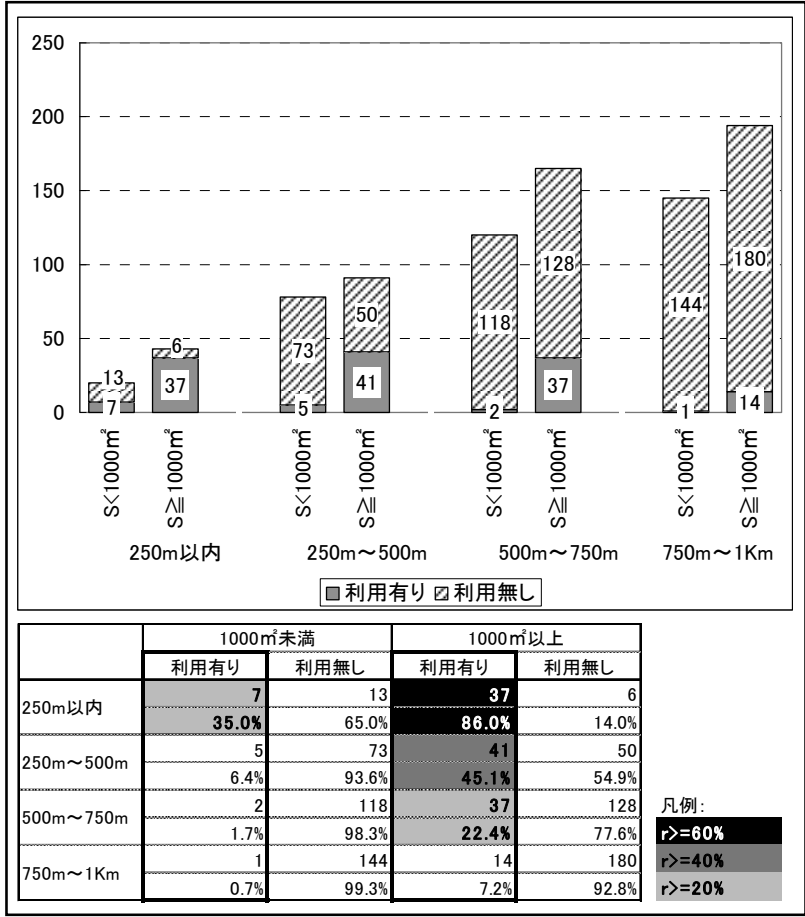

図一4 公園利用有無の比較（面積階級別）

（3）園外活動利用に影響を及ぼす都市公園施設条件の考察

ヒアリング調査で得られた公園利用上の課題・要望について一 覧表にまとめた (表一 3 )。「公園施設」に関する指摘が 62 件，「他 の利用者との関係」に関する指摘が 5 件見られた。「公園施設」 に関する指摘では「遊具」に関寸る指摘が 24 件，「トイレ」に関 する指摘が 17 件と多く見られた。さらに「遊具」に関する指摘 のうち「幼児向け遊具」に関する指摘が 17 件，「対象年齢の告知」 に関する指摘が 5 件見られ，「トイレ」に関する指摘のうち「ト イレの必要性」に関する指摘が 10 件，「和式洋式」に関する指摘 が 6 件見られた。この結果を踏まえ，これらの公園施設の有無と 園外活動利用の有無の関係について分析を行った。またこれらの 関係性を説明する根拠として，ヒアリング調査結果の言説データ
表－3 園外活動利用の課題・要望（ヒアリング調査から）

\begin{tabular}{|c|c|c|}
\hline 大分類 & 中分類 & 小分類 \\
\hline \multirow[t]{9}{*}{$\begin{array}{l}\text { 公園施設 } \\
\text { (62) }\end{array}$} & 遊具 (24) & $\begin{array}{l}\text { 幼児向け遊具 (17)，対象年 } \\
\text { 齢の告知 (5)，遊具の素材 } \\
\text { (1)，遊具の老朽化 (1) }\end{array}$ \\
\hline & トイレ(17) & $\begin{array}{l}\text { トイレの必要性 }(10) \text { ，和式 } \\
\text { 洋式 }(6) \text { ，身障者用トイレ (1) }\end{array}$ \\
\hline & 施設設置要望 (8) & $\begin{array}{l}\text { 外柵の設置 (4), 時計の設置 } \\
\text { (2), 噴水の設置 }(1) \text {, 手すり } \\
\text { 設置 (1) }\end{array}$ \\
\hline & 施設の配置 (4) & 施設のゾーン分け(2)，事故の \\
\hline & 健康器具 (2) & 事故の恐れ (2) \\
\hline & 植栽(2) & 緑陰の不足 (2) \\
\hline & 水飲み場 (2) & 手洗いの必要性(2) \\
\hline & 砂場 (2) & 動物のフン (2) \\
\hline & 築山(1) & 死角の発生 $(1)$ \\
\hline \multirow[t]{2}{*}{$\begin{array}{l}\text { 他の利用者 } \\
\text { との関係 (5) }\end{array}$} & $\begin{array}{l}\text { ペツト連れ利用者 } \\
\text { (4) }\end{array}$ & 事故の恐れ (4) \\
\hline & $\begin{array}{l}\text { 他の保育施設利 } \\
\text { 用者 }(1)\end{array}$ & 利用のバッテイング(1) \\
\hline
\end{tabular}

\section{を提示した。}

利用の見られた都市公園について幼児向け遊具設置の有無を確 認した結果, 166 力所中 76 力所 (45.8\%) の利用有り都市公園に 幼児向け遊具が設置されていた（図一4)。さらにこの結果とアン ケート調査結果をもとに，利用有り都市公園の利用者属性を「2 歳児以下」,「3 歳児以上」の 2 区分で分析した結果，2 歳児以下 の利用が見られた都市公園では幼児向け遊具の設置が $40 \%$ 以下 にとどまったのに対し，3 歳児以上のみが利用する都市公園にお いては 77 力所中 41 力所 $(53.2 \%)$ で幼児向け遊具の設置が確認 された（表一4）。この結果についてヒアリング調査結果を検証し た結果 (表一 5 ), 「2 歳児だと遊具で遊べない, 「遊具をあてにせ ず築山や遊歩道を歩く」,「(遊べる遊具の) 条件は小さい子の方が 狭くなる」，「年齢が低い幼児が遊べる遊具は限られる」など， 2 歳児以下の幼児は保育士等から見た場合，都市公園の固定遊具で 遊ぶには安全性の確保が難しいと判断される場合が多々あると推 察され，都市公園内の幼児向け遊具があることが必ずしも園外活 動の場として利用されることに結びついてはいないことが明らか 


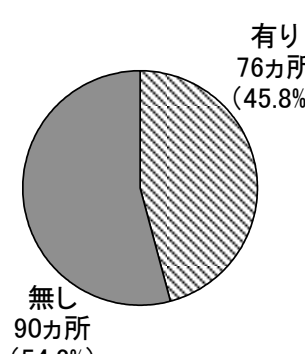

(54.2\%)

図一5 利用有り都市公園 幼児向け遊具の有無

表一4 幼児向け遊具の有無（利用年齢別）

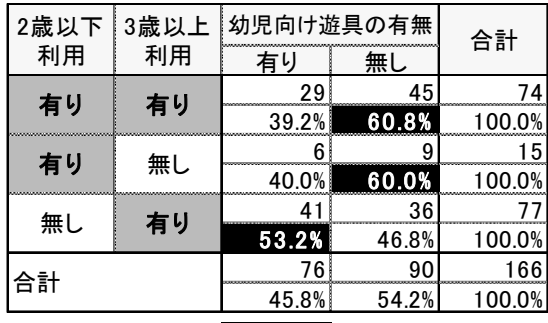

凡例 : $\mathbf{r}\rangle=\mathbf{5 0 \%}$

表一5 幼児向け遊具に関する言説（ヒアリング調査から）

\begin{tabular}{|c|c|c|}
\hline 施設区分 & $\begin{array}{c}\text { 施設 } \\
\text { No. }\end{array}$ & 言説 \\
\hline 認可保育所 & 9 & $\begin{array}{l}\text { 歲児だと遊具で遊べない。けがをしないようにと思うと、保育士 } \\
\text { が2人ついていても見るところが必要になる。2人でいるときは遊 } \\
\text { 具が使えないことが多く、遊具をあてにせず築山や遊歩道を歩 } \\
\text { く. }\end{array}$ \\
\hline 認可保育所 & 7 & $\begin{array}{l}\text { 美しが丘めるへん公園のすべり台は1，2歳が遊ぶにはは少し高 } \\
\text { い。近いところしか行けないので、近い公園を利用する。そこの } \\
\text { 公園で遊具で遊ぶとしたら使えるものを判断して、それでしか遊 } \\
\text { ばない。(遊べる遊具の)条件は小さい子の方が狭くなる。 }\end{array}$ \\
\hline 認可保育所 & 10 & $\begin{array}{l}\text { 中央公園は大型の複合遊具がおいてあるが、0歳、1歳、2歳が } \\
\text { 遊ぶには怖くて使わない。年齢が低い幼児が遊べる遊具は限ら } \\
\text { れるので、あまり大型でなくていい。面積も広くなくてもいい。行 } \\
\text { 動範围が狭いし、動きも限られる。 }\end{array}$ \\
\hline 幼稚園 & 23 & $\begin{array}{l}\text { 美しが丘西公園は遊具が高めで、どちらかというと年長向け。年 } \\
\text { 少を連れて行ったこはある゙補助がかなり必要だった。それに } \\
\text { 比へ新栄東公園は比較的遊具が低めなのと、遊具があるところ } \\
\text { が狭いので、保育士が見やすい。 }\end{array}$ \\
\hline
\end{tabular}

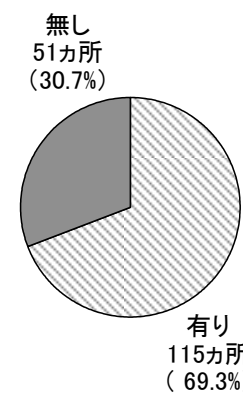

表一6 トイレの有無（利用年齢別）

\begin{tabular}{|c|c|c|c|c|}
\hline $\begin{array}{l}\text { 2歳以下 } \\
\text { 利用 }\end{array}$ & $\begin{array}{l}3 \text { 歳以上 } \\
\text { 利用 }\end{array}$ & $\begin{array}{l}\text { トイレ } \\
\text { 有り }\end{array}$ & $\begin{array}{l}\text { トイレ } \\
\text { 無し }\end{array}$ & 合計 \\
\hline \multirow{2}{*}{ 有り } & \multirow{2}{*}{ 有り } & 5 & 24 & 74 \\
\hline & & $67.6 \%$ & $32.4 \%$ & $100.0 \%$ \\
\hline \multirow{2}{*}{ 有り } & \multirow{2}{*}{ 無し } & 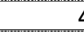 & 11 & 15 \\
\hline & & 26.70 & $73.3 \%$ & $100.0 \%$ \\
\hline \multirow{2}{*}{ 無し } & \multirow{2}{*}{ 有り } & 6 & 16 & 77 \\
\hline & & $79.2 \%$ & $20.8 \%$ & $100.0 \%$ \\
\hline \multirow{2}{*}{\multicolumn{2}{|c|}{ 合計 }} & 115 & $\begin{array}{r}51 \\
\end{array}$ & 166 \\
\hline & & $69.3^{\circ}$ & $30.7 \%$ & $100.0 \%$ \\
\hline
\end{tabular}

図一6 利用有り都市公園

トイレの有無

表ー7 公園内トイレに関する言説（ヒアリング調査から）

\begin{tabular}{|c|c|c|}
\hline 施設区分 & $\begin{array}{l}\text { 施設 } \\
\text { No. }\end{array}$ & 言説 \\
\hline 認定こども園 & 1 & $\begin{array}{l}\text { (おむつがとれた3歳以上は)公園のトイレを使う。春通り } \\
\text { 公園と夏通りり緑地にはトイん゙いのであま行けナな } \\
\text { い,トイレがない公園はどうしても足が遠のく }\end{array}$ \\
\hline 認可保育所 & 11 & $\begin{array}{l}\text { 荿になるとおむつが外れるのでなるべくトイしのある公 } \\
\text { 袁に行く大きい公園に行くことが多いが、大きい公園に } \\
\text { はトイがついている。 }\end{array}$ \\
\hline 幼稚園 & 17 & $\begin{array}{l}\text { 歲児は使ったことなく和式が苦手、全部でなくていいが } \\
\text { 羊式の方が扱いやすい。和式は先生が必ずついて行く。 }\end{array}$ \\
\hline 幼稚園 & 22 & $\begin{array}{l}\text { 洋式があった方がいい。女の子は先生がー人うう抱え } \\
\text { て抱っこしながら手伝う。 }\end{array}$ \\
\hline 幼稚園 & 23 & 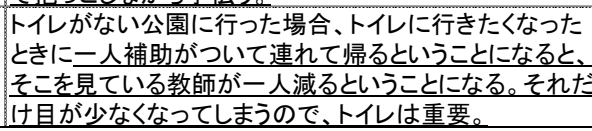 \\
\hline
\end{tabular}

となった。一方で 3 歳児以上の幼児の場合は, 保育施設の園外活 動において都市公園内の遊具を使用していたことから，都市公園 内に幼児向け遊具の設置が 3 歳児以上の幼児を引率した園外活動 利用の促進につながるのではないかと推察された。

次に，園外活動利用の見られた都市公園についてトイレ設置の 有無について分析した結果，166 力所中 115 力所 (69.3\%) の都 市公園においてトイレの設置が確認された（図一6)。前述の幼児 向け遊具の有無と同様，利用有り都市公園の利用者属性を「2 歳
表一8 年齢表示シールと利用に関する言説（ヒアリング調査から）

\begin{tabular}{|c|c|c|}
\hline 施設区分 & $\begin{array}{l}\text { 施設 } \\
\text { No. }\end{array}$ & 言説 \\
\hline 認可保育所 & 5 & $\begin{array}{l}\text { (公園遊具の) 対象年齢が6歳から12歳と言われていいい対象年齢 } \\
\text { に達していないのは使わないというが基本方針。 }\end{array}$ \\
\hline 認可保育所 & 5 & 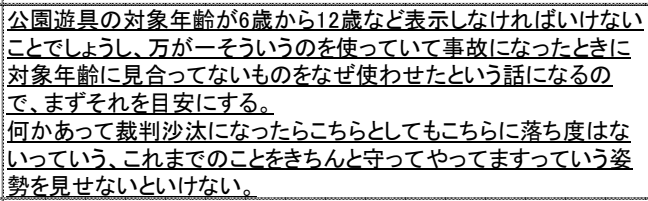 \\
\hline 認可保育所 & 17 & 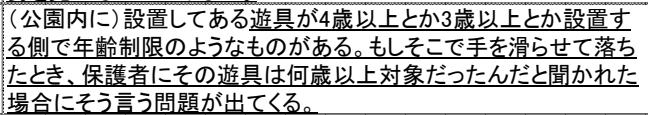 \\
\hline 認可保育所 & 18 & $\begin{array}{l}\text { 何歳以上対象というのがあると先生たちもそれを見る。(保育士 } \\
\text { は)見ただけでもこどもの身長を見れば遊べるか遊べないは判断 } \\
\text { できるが、広い公園に行っても今日はここはだめここだけで斿ぼ } \\
\text { うという指示で遊んでいる。公園に遊具があっても遊べないことが } \\
\text { ある。 }\end{array}$ \\
\hline
\end{tabular}

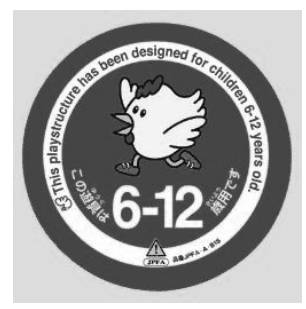

図-7 年齢表示シール例

児以下」,「3 歳児以上」の 2 区分で分析した結果， 2 歳児以下の みでの利用が見られた都市公園でトイレが設置されていたのは

15 力所中 4 力所のみ (26.7\%) にとどまった（表一6)。この理由 についてヒアリング調査結果を確認した結果 (表一 7$)$,「(2 歳児 は）ほとんどおむつでトイレに困ることはない,「3 歳になると おむつが外れるのでなるべくトイレのある公園に行く」など，日 常的におむつを使用しているか娝かが 2 歳児以下と 3 歳児以上で 大きく異なり, 3 歳児以上の幼児を引率した都市公園利用の際に はトイレが設置されていることが重要な選択条件になっているこ とが明らかとなった。またトイレの形態として幼児は和式トイレ の使用経験がそしく，利用の際に引率職員の付き添いが必要とな り, 洋式トイレの設置要望が複数確認された。さらに特筆すべき 状況として「トイレがない公園に行ってトイレに行きたくなった ときに連れて帰ることになると，そこを見ている教師が一人減る ことになり，それだけ目が少なくなってしまう」との指摘があっ た（表一7）。すなわち 3 歳児以上の幼児を引率した際, 活動場所 となる都市公園にトイレが設置されていないという状況が，引率 する幼児全体の安全確保にまで影響を及ぼす要因にもなりかねな いことが明らかとなった。

このほか利用に影響を及ぼす都市公園施設条件として，遊具に 貼り付けられた年齢表示シール 17)が施設の使用に少なからず影 響を与えていることが確認された（表－8，図一7）。ヒアリング 調查結果から, 都市公園内の遊具に貼られている対象年齢シール が引率幼児の年齢に該当していない場合, 事故が起きた場合の保 護責任を問われる可能性があることから使用しないようにしてい る，といら方針を立てている保育施設の存在が確認された（表一 8)。国土交通省は「都市公園における遊具の安全確保に関寸る指 針 (改訂第 2 版)」18) において年齢表示シールを提示しているが, 本研究で対象とした都市公園管理者である札幌市みどりの推進部 に対して年齢表示シール貼り付けの意図を照会した結果, 「都市公 園の遊具における対象年齢の設定・周知については，遊具を安全 に使用していただくための「利用者及び保護者への使用上の注意 喚起」を目的としている。なお, 対象年齢に合致しない場合でも, その使用を禁止するものではない。との回答が得られた。すなわ 
ち公園管理側としては，あくまで遊具の安全使用推進を志向した 告知であり，年齢による使用の制限を意図したものではないが， 一部の保育施設公園利用者の受け止め方は管理者側の意図と異な り，引率幼児の保護責任の観点から公園施設の使用制限を強化す る対応をとらざるを得ない状況であることが明らかとなった。

\section{4. まとめ}

本研究は各保育施設における幼児人数や園外活動における年齢 構成，園庭の有無等の基本条件を整理した上で，保育施設の園外 活動の場としての都市公園利用の実態を把握すること，園外活動 の場として利用される都市公園の保育施設からの距離, 都市公園 面積などの空間条件を明らかにすること，引率する幼児の年齢な ど利用者属性と上記 $2 つ の$ 目的との関係性について分析・考察す ること，の 3 点を目的として調査・研究を行った。各保育施設の 園庭の有無と面積について整理した結果，認定こども園，認可保 育所，幼稚園はすべて園庭が設置されていたのに対し，認可外保 育所ではすべて園庭が設置されていなかった。園庭の面積規模で は幼稚園は規模が大きかったのに対し，認可保育所では面積規模 の小さい事例が多く見られ，施設の分類による差異が見られた。

GIS を用いて各保育施設から園外活動の場となる都市公園までの 距離，分布を把握した結果，保育施設の区分（認定こども園，認 可保育所，認可外保育所，幼稚園）による都市公園利用の差異が 認められ, 認定こども園, 認可保育所では施設から $1 \mathrm{Km}$ 圈内, 認可外保育所では施設から $750 \mathrm{~m}$ 圈内の複数の都市公園利用が見 られた。これに対して，送迎バスを所持する幼稚園では，園外活 動の際の移動手段として徒歩以外にバスを使用し,施設から $1 \mathrm{Km}$ 以遠の都市公園を利用している実態が確認された。このうち認可 外保育所は都市公園利用数が多い傾向が見られた，園庭の面積規 模が比較的小さいことから年齢別のクラスごとに園庭と園外の都 市公園を使い分けているためではないかと推察された。また園庭 を所有しない認可外保育所は都市公園等が屋外活動の場となるも のの, 1 歳から 5 歳まですべて引率する形態であることから利用 できる公園数や移動距離が限定的となっていると考えられた。ま た各保育施設周辺における都市公園分布についての実態把握を行 い, 公園面積 $1,000 \mathrm{~m}^{2}$ 未満と $1,000 \mathrm{~m}^{2}$ 以上で公園利用の有無を比 較した結果，保育施設からの距離が遠くなるにしたがって面積規 模の小さい都市公園の利用比率が顕著に減少していくことが明ら かとなった。またヒアリング調査で得られた公園利用上の課題・ 要望を集計した結果，公園施設の中でも特に幼児向け遊具と卜イ レに関する指摘が多く見られたことから, 特定の都市公園施設 (幼 児向け遊具，トイレ）の有無と園外活動利用の有無の関係につい て分析を行った結果, 幼児向け遊具では 2 歳児以下の利用が見ら れた都市公園で設置が $40 \%$ 以下であったのに対し，3歳児以上の みが利用する都市公園では $53.2 \%$ で幼児向け遊具の設置が確認さ れた。理由としてヒアリング調査結果から，2 歳児以下の幼児は 都市公園の固定遊具で遊ぶには安全性の確保が難しいと判断され る場合があり，幼児向け遊具があることが必ずしも園外活動の場 としての利用に結びついてはいなかった。また園外活動に利用さ れていた都市公園のトイレ設置有無を分析した結果, 166 力所中 115 カ所 $(69.3 \%)$ でトイレの設置が確認されたが, 2 歳巟以下の み利用寸る都市公園のトイレ設置は 15 力所中 4 力所 (26.7\%) に とどまり，2 歳児以下の幼児がおむるる着用していることがその 理由となっていた。その一方で，3 歳児以上の幼児では都市公園 内にトイレが設置されていることが保育施設による利用公園選択 の重要な要件となっており, 都市公園内にトイレが設置されてい ない状況が引率する幼児全体の安全確保にまで影響を与えること が明らかとなった。またトイレの形態として和式トイレは利用の 際に引率職員の付き添いが必要となり, 洋式トイレの設置を要望
する意見が複数確認された。このほか公園内施設（遊具）の安全 使用推進を目的に公園管理者から提示された対象年齢シールが, 事故による保護責任リスクを懸念する一部の保育施設で，公園施 設の使用制限を強化する結果となっている実態が明らかとなった。

以上の結果から，今後保育施設の園外活動促進に向けた都市公 園のあり方として，2 歳児以下の幼児が入所する認定こども園や 保育所の $500 \mathrm{~m}$ 圏内に, 少なくとも面積 $1,000 \mathrm{~m}^{2}$ 以上の都市公園 が 1 力所以上整備されているか否かを確認し, 不足する地区にあ っては対応を検討すべきではないかと考えられた。また 2 歳児以 下の幼児を主な利用対象と見込む場合には，幼児向け遊具よりも 芝生広場, 築山等の公園施設の整備, 導入を検討すべき点が指摘 された。一方で 3 歳児以上の幼児利用による園外活動を想定した 場合，トイレの設置が保育施設利用の利便性向上に寄与するのみ ならず,引率幼巟全体の安全確保を担保寸るためにも重要であり, 洋式トイレの設置も検討寸べきと考えられた。さらに都市公園内 の遊具に提示された対象年齢シールに関しては，公園管理者と公 園利用者の間に認識の隔たりがあることが十分想定されることか ら，今後は公園管理者側から対象年齢告知の意図について積極的 な情報発信が必要と考えられる。

\section{補注及び引用文献}

1）三輪律江・尾木まり（2017）：まち保育のススメ, 萌文社

2) 厚生労働省 (2017) : 保育所保育指針

3）文部科学省 (2017) : 幼稚園教育要領

4) 内閣府 (2017) : 幼保連携型認定こども園教育・保育要領

5) 松橋圭子・三輪律江・田中稲子・谷口 新・大原 一興・藤岡 泰宽 (2010) : 保 育施設における屋外環境と園外活動の実態から夕た地域資源のあり方に関寸る 研究 一横浜市を対象としたアンケート調査よりー, 日本建築学会計画系論文集 No.651，1017-1024

6）三輪律江・田中稲子・松橋圭子・谷口新・田村明弘 (2008) : 保育施設の「屋外 遊戯場」としての公園の代替利用に関寸る研究 -横浜市における保育施設を対 象としたアンケート調査より-，都市計画論文集 43-3，907-912

7）田中稲子・三輪律江・松橋圭子・谷口新 (2009) : 横浜市における駅前保育施設 の園外活動の場としての街区公園利用とその評価に関する研究, 都市計画論文集 No.44-3, 373-378

8）椎野覀紀夫 (2011) : 保育施設の立地状況と都市公園分布との関倸性に関する検 討，造園技術報告集 $6 ， 22-25$

9）保育所とは児童福祉法第 7 条に規定される「児童福禅施設」，幼稚園とは学校教 育法第 1 条に規定される「学校」, 認定こども園とは就学前の子どもに関する教 育，保育等の総合的な提供の推進に関寸る法律第 3 条に規定される「子育て支 援の総合的な提供を行う施設」に該当するが, 本稿ではこれらの施設を幼児の健 全な発達支援を目的とした施設として「保育施設」と定義した。近年では保育施 設として小規模保育, 家庭的保育, 事業所内保育等が含まれるが, 調査時点で対 象地における事例が確忍されておららず，本研究の対象には含まれていない。

10）椎野覀紀夫 (2007) : 保育施設による都市公園の選択的利用に関する事例研究 ランドスケープ研究70(5), 637-642

11）保育所または認定こども園に設置される「屋外遊戯場」、幼稚園に設置される「運 動場」を本研究では「園庭」と呼称寸る。

12）国土数值情報ダウンロードサービス, 国土交通省国土政策局国土情報課ホームペ —ジ<http://nlftp.mlit.go.jp/ksj/> , 2016.9.14 参照

13）幼稚園が送迎バスを利用して $1 \mathrm{Km}$ 以遠の公園を利用する形態は, 年中行事の一 つである遠足としての利用も想定されるが, 本稿においてはアンケート調査, ヒ アリング調査において年中行事やイベント等ではなく日常的な園外活動として の都市公園利用を研究対象としており, 本稿でデータ提示した幼稚園による $1 \mathrm{Km}$ 以遠の都市公園利用は日常的な園外活動であることを確認している。

14）既存研究 ${ }^{5}$ に において利用の多寊に影響与える公園面積規模の閾值として「1,000 $\mathrm{m}^{2} 」$ が指摘されていること, また札幌市緑の審議会による『身近な公園の新規 整備方針』策定に向けた基本的な考え方」 ${ }^{16}$ ににおける地域の核となる公園を「概 ね面積 $1,000 \mathrm{~m}^{2}$ 以上の公園」としていること等を踏まえ, 利用の有無を比較する

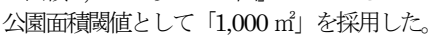

15）椎野亜紀夫・愛甲哲也（2014）：览童の年龄差による都市公園選択の差異に関す る研究一小学校区を単位とした都市公園配置の差異の検証一, 都市計画論文集 49-3, 267-272

16）札幌市みどりの推進部（2016）:「身近な公園の新規整備方針」策定に向けた基 本的な考え方につい,

http://www.city.sapporo.jp/ryokuka/midori/forest/skeika/toushin/mijikanapar k.html, 2018.4 参照

17）日本公園施設業協会:安全利用表示, https://www.jpfa.or.jp/certification/anzen/, 2018.11 参照

18）国土交通省 (2014)：「都市公園における遊具の安全確保に関寸る指針 (改訂第2 版」, http://www.mlit.go.jp/common/000022126.pdf, 2018.4 参照 